\title{
PENGARUH PENGETAHUAN AGAMA DAN PERTIMBANGAN MORAL TERHADAP AGRESIVITAS SISWA MAN KABUPATEN BUNGO
}

\author{
Fitria Carli Wiseza \\ Sekolah Tinggi Agama Islam (STAI) Yasni Muara Bungo \\ e-mail: fitriacarliwiseza@staiyasnibungo.ac.id \\ Noviriani \\ Sekolah Tinggi Agama Islam (STAI) Yasni Muara Bungo \\ e-mail: riani.tazky@gmail.com
}

\begin{abstract}
Education must be able to help students to become knowledgeable, good behaviour, be able to live with other people and have skills in applying their knowledges in society. The purpose of this research was to see the extent of the influence of religious knowledge and moral considerations toward aggressiveness of MAN students. This research was used multistage random sampling technique, selected MAN 1, MAN 2 and MAN 3 as many as 580 students and the number of samples through the Tuckman formula was 263 respondents. To collect the data this research used observation, questionnaires and documentation. The data were analyzed by the t-test formula and ANOVA. After the analysis, the result of this research was concluded, (1) there is an influence of religious knowledge toward the aggressiveness of MAN students of Bungo, (2) there is an influence of moral consideration toward aggressiveness of MAN students of Bungo, (3) there is an influence of religious knowledge and moral considerations toward aggressiveness of MAN students of Bungo. The higher the religious knowledge and moral considerations applied in daily life, the less aggressive behavior of students.
\end{abstract}

Keywords: Religious Knowledge, Moral Consideration, Aggressiveness Students.

\begin{abstract}
Abstrak
Pendidikan harus dapat membantu peserta didik untuk menjadi manusia yang berilmu pengetahuan, berakhlak mulia, dapat hidup bersama orang lain dan memiliki ketrampilan dalam mengaplikasikan ilmunya di masyarakat. Penelitian ini bertujuan untuk melihat sejauhmana pengaruh pengetahuan Agama dan pertimbangan moral terhadap agresivitas siswa. Dalam penelitian ini digunakan teknik pengambilan sampel Multistage random Sampling, terpilih MAN 1, MAN 3 dan MAN Labor sebanyak 580 siswa serta jumlah sampel melalui rumus Tuckman sebesar 263
\end{abstract}

Nur El-Islam, Volume 5, Nomor 2, Oktober 2018 
responden. Teknik pengumpulan data melalui observasi, kuesioner serta dokumentasi. Teknik analisis data dalam penelitian ini melalui uji t dan anova. Setelah dilakukan analisis diperoleh kesimpulan (1) terdapat pengaruh pengetahuan agama terhadap agresivitas siswa MAN Kabupaten Bungo, (2) terdapat pengaruh pertimbangan moral terhadap agresivitas siswa MAN Kabupaten Bungo, (3) terdapat pengaruh pengetahuan agama dan pertimbangan moral terhadap agresivitas siswa MAN Kabupaten Bungo. Semakin tinggi Pengetahuan agama dan pertimbangan moral yang diterapkan dalam kehidupan sehari-hari maka semakin minim perilaku agresivitas siswa.

Kata kunci: Pengetahuan Agama, Pertimbangan Moral dan Agresivitas Siswa.

\section{A. Pendahuluan}

Taxonomi Bloom, menjelaskan bahwa pendidikan tidak hanya bertujuan membuat peserta didik menjadi orang yang kaya ilmu pengetahuan dan teori, tetapi juga membentuk manusia yang mampu bertingkah laku baik di dalam masyarakat sekaligus keterampilan dalam mempraktikkan ilmu yang dimilikinya. ${ }^{1}$ Gilliland dengan teori multiple intelligence nya mengemukakan bahwa, selain akademik aspek-aspek kemampuan yang berpengaruh besar terhadap keberhasilan seseorang adalah intrapersonal dan interpersonal. ${ }^{2}$ Dainel Goleman mengemukakan bahwa kontribusi IQ terhadap keberhasilan hidup seseorang hanya $20 \%$, sedangkan $80 \%$ selebihnya adalah kemampuan lain seperti kemampuan mengelola emosi yang disebut Emotional Quition. ${ }^{3}$

Pendidikan tidak hanya berorietasi kepada pemenuhan kebutuhan kognisi peserta didik, tetapi juga kebutuhan afeksi dan psikomotorinya. Implikasinya, secara ideal pendidikan harus dapat membantu peserta didik untuk menjadi manusia yang berilmu pengetahuan, berakhlak mulia, dapat hidup bersama orang lain dan memiliki ketrampilan dalam mengaplikasikan ilmunya di masyarakat. Pendidikan yang ideal harus mencakup tiga ranah tersebut. Perhatian

\footnotetext{
${ }^{1}$ Bloom, B. S. ed. et al. Taxonomy of Educational Objectives: Handbook 1, Cognitive Domain (New York: David McKay, 1999), h. 234.

${ }^{2}$ Gilliland et.al, Theories and Stategies In Counseling and Psychoteraphy (New Jersey: Prentice Hall Inc, 1999), h. 23.

${ }^{3}$ Elizabeth Hurlock B, Perkembangan Anak, Jilid 4, Edisi Keenam (Jakarta: Erlangga, 2001), h. 34.
} 
yang berlebihan terhadap transfer pengetahuan hanya akan menghasilkan banyak orang pintar tetapi kurang arif dalam bertindak. Secara faktual, hasil yang dicapai masih belum sinkron dengan tujuan yang diharapkan. Banyak peserta didik yang memperlihatkan perilaku menyimpang, misalnya agresivitas yang menimbulkan keresahan di dalam masyarakat luas.

Bloom mengklasifikasi kemampuan dasar manusia menjadi tiga ranah yaitu kemampuan kognitif, afektif dan psikomotorik. Berdasarkan klasifikasi tersebut, pengetahuan merupakan kognitif. Selanjutnya, Bloom dalam Anderson dan Kratwoth menyusun kemampuan kognitif ke dalam tingkatan yang dimulai dari kemampuan paling rendah sampai tingkat paling tinggi. Enam tingkatan kognitif yang dimaksud itu adalah ingatan, pemahaman, penerapan, analisis, evaluasi dan kreasi. ${ }^{4}$ Selanjutnya, menurut Azwar dimensi pengetahuan merupakan kemampuan kemampuan kognitif yang terdiri atas pengetahuan faktual, pengetahuan konseptual, pengetahuan prosedural, dan pengetahuan meta-kognitif. ${ }^{5}$

Menurut Yusuf Moral berarti adat istiadat, kebiasaan-kebiasaan, aturan, nilai dan tata cara. ${ }^{6}$ Menurut Dewey dalam Ali dan Asrori Moral berarti hal-hal yang berhubungan dengan nilai-nilai susila. ${ }^{7}$ Sedangkan Menurut Baron Moral adalah hal yang berhubungan dengan larangan dan tindakan yang berbicara tentang salah atau benar. Menurut Shaffer dalam (Budiningsih) Moral pada dasarnya merupakan rangkaian nilai tentang berbagai macam perilaku yang harus dipatuhi oleh seseorang. Kata moral mengacu kepada kehidupan manusia yang memandang dari segi kebaikan. Norma yang dipakai dalam masyarakat merupakan tolak ukur menilai kebaikan itu.

\footnotetext{
${ }^{4}$ Anderson Lorin W. And David R. Krathwoh. A, Taxonomi For Learning, Teaching and Assessing: A Revision of Blooms Taxonomy of Educational Objecteves (New York: Addison Wsley Longman,Inc, 2001), h. 21.

${ }^{5}$ Azwar Saifuddin, Reliabilitas dan Validitas (Yogyakarta: Pustakawa Pelajar, 2000), h. 60.

${ }^{6}$ Yusuf Syamsu, Psikologi Perkembangan Anak dan Remaja (Bandung: Remaja Rosdakarya, 2004), h. 132.

${ }^{7}$ Ali Mohd dan Asrori Mohd. Psikologi Remaja: Perkembangan Peserta Didik (Jakarta: Bumi Aksara, 2004), h. 136.
} 
Sehubungan dengan perkembangan remaja, Piaget dan Kohlberg memandang bahwa molaritas berkaitan erat dengan empati yaitu merasakan apa yang ia rasakan oleh orang lain. Orang yang memiliki empati pada dirinya tertanam pertimbangan moral sebagai aktivitas rasio dan perasaan.Perkembangan pertimbangan moral ke dalam tiga tingkat, yaitu (1) prakonvensional awal tingkat beroreantasi kepatuhan sosial dan hukuman, tingkat beroreantasi individualis dan instrumentalis. ${ }^{8}$ Barger, (2) konvensional dialami seseorang berkaitan dengan masyarakat karena masyarakat mengharapkannya untuk berbuat baik jika tidak bertentangan dengan aturan dan norma yang berlaku dalam masyarakat itu (3) pascakonvensional, lebih menonjol ialah rasa takut, maka pada tingkat konvensioanal yang lebih menonjol adalah rasa malu. ${ }^{9}$

Mahfuzh, ia mengatakan, akhir-akhir ini telah banyak terjadi perilaku menyimpang di kalangan sekolah, khususnya siswa pada tingkat Sekolah Menengah Atas (SMA). Ciri-ciri perilaku menyimpang tersebut antara lain: terlambat mengikuti pelajaran, kabur dari sekolah, absen dari mata pelajaran, berontak terhadap peraturan sekolah, berbohong, berlagak seperti lawan jenis, berperilaku anarkis, berbuat cabul, problem gender, merokok, memusuhi teman, membuat gank, tidak patuh kepada orang tuan, mencuri dan memusuhi guru. ${ }^{10}$ Harapan bahwa agresi adalah suatu tingkah laku yang bertujuan untuk melukai individu lain baik secara fisik maupun non fisik. ${ }^{11}$

Sementara itu Sears mengartikan agresi sebagai serangan yang dilakukan oleh makhluk hidup lainnya yang dijadikan objek serangan. Dari pengertian di atas diketahui adanya faktor-faktor yang menyebabkan suatu perilaku agresi yaitu (1) tujuan untuk menyakiti

\footnotetext{
${ }^{8}$ Budiningsih, Pembelajaran Moral (Jakarta: Rineka Cipta, 2004), h. 24.

9 Barger Robert N, “A Summy of Lawrence Kohlberg's Stages of Moral Developmnet"Makalah (Notre Dame: University of Notre Dame, 2000), h. 1.

${ }^{10}$ Mahfuzh Jamaluddin, Psikologi Anak dan Remaja Muslim (Jakarta: Pustaka AlKautsar, 2001), h. 174.

${ }^{11}$ Harapan Ponpon, “Agresi Pada Remaja "Makalah disampaikan pada seminar Tindakan Kekerasan dan Agresi di Kalangan Anak dan Remaja Bandung 07 Sepetember 1991.
} 
atau mencelakai seseorang (2) individu yang bertindak sebagai pelaku agresi(3) individu menjadi sasaran korban (4) ketidakinginan korban menerima perlakuan yang merugikan. ${ }^{12}$

Menurut Mark Agresivitas mempunyai kaitan yang erat dengan masalah-masalah sebagai berikut (1) karakteristik individu seperti intelligensi, hiperaktif, dan keadaan miskin (2) lingkungan rumah seperti tidak harmonis dan perilaku yang tidak sedikitpun memberi kebebasan kepada anak (3) hubungan tidak harmonis dengan teman sebaya yang disebabkan oleh kurangya ketrampilan sosial (4) kegagalan sekolah (5) ekspose tindak kekerasan dalam media massa. Mark membedakan agresi menjadi tiga macam yaitu agresi fisik,agresi verbal dan agresi tidak langsung. Agresi fisik meliputi perilakuperilaku mendesak, Mendorong, memukul, menampar, menarik, menendang, menarik rambut, menikam, mnembak dan memperkosa. Agresi verbal seperti mengolok-ngolok. Pada level yang paling dasar agresi manusia terkait dengan perilaku fisik atau verbal. Dalam agresi tidak langsung, perilaku yang menonjol antara lain membuat gossip, menyebarkan rumor yang mengacaukan dan mengajak seseorang untuk menolak atau mengucilkan orang lain. ${ }^{13}$

Berdasarkan observasi awal yang dilakukan peneliti di sekolah MAN 1 Muara Bungo, Peneliti melihat sebagian siswanya ada yang menunjukkan sikap perilaku non-sosial dalam kontek proses kegiatan Pembelajaran diantaranya terlambat dalam mengikuti pelajaran, bolos dalam jam pelajaran, kurangnya disiplin peserta didik, melanggar peraturan sekolah dan kurangnya tanggung jawab akan kewajiban sebagai peserta didik seperti tugas yang diberikan guru, meninggalkan jam pelajaran dan berkeliaran diluar lokasi sekolah, berbohong dan bahkan kurangnya rasa sopan santun serta menghargai siswa terhadap gurunya. Hal itu semua termasuk agresivitas verbal bahkan Kenyataan lain yang peneliti lihat di lapangan sampai melakukan tindakan tawuran antar peserta didik bersumber dari olok-olakan ,serta aksi

12 Sears David et.al, Psikologi Sosial (Jakarta: Erlangga, 1991), h. 67.

13 Mark Ruth, Aggression.2002(http://specialed.about.com/cs/behavior encourders/a/aggression.html. Diakses pada tanggal 1 Februari 2018. 
coret -coretan yang baru ini dilakukan peserta didik dalam menunjukkan kegembiraan setelah ujian nasional sehingga memblokade jalan raya sehingga menjadi macet, itu semua merupakan agresivitas fisik yang menunjukkan emosional dari siswa yang tak terkendali maupun terkontrol sehingga dapat menyakiti dan mengganggu orang lain. Kenyataan lainnya, pengaruh arus globalisasi dan perkembangan IPTEK saat sekarang ini, yang melanda dan merusak generasi muda terutama para remaja seperti penyalagunaan narkoba, terkait dengan hal ini berdasarkan data dari polres bungo, kasus narkoba merupakan kasus nomor 2 terbesar di provinsi Jambi, mengingat hal ini sangat besar pengaruhnya terhadap remaja karena penyalahgunaa narkoba umumnya berawal dari pergaulan lingkungan terutama merokok, merokok di kalangan para siswa tidak asing lagi mata kita memandangnya, terkadangpun sering sekali peneliti menemui di lapangan para siswa masih dalam pakaian lengkap sekolah merokok di sekitaran jalan raya. Merokok tentunya akan menjadi kebiasaaan nantinya setelah mereka akan coba-coba terhadap narkoba dan ujungnya kecanduan.

Fakta Lainnya yang peneliti lihat dilapangan, Pergaulan terhadap lawan jenis, para remaja tidak malu untuk pacaran di depan umum yang lari dari kaedah agama islam sehingga berpengaruh terhadap pergaulan bebas. Hal ini tentunya, menjadi perhatian kita bersama terutama lembaga pendidikan, akibat minimnya nilai keagamaan yang mereka miliki, pengaruh lingkungan yang buruk. pada kenyataannya nilai agama sangatlah penting, nilai agama akan memberikan panduan kepada manusia berhubungan dengan tuhan. Hubungan manusia tuhannya ini sangat penting untuk membatasi tingkah laku manusia. Dengan demikian, manusia dapat membedakan mana yang benar dan mana yang salah dalam kehidupan ini sehingga dapat mempertimbangan moral. Pernyataan ini didukung dengan data persentase siswa bermasalah yang terdata pada catatan BK di sekolah penelitian pada 2 tahun terakhir sebagai berikut:

\begin{tabular}{|l|l|l|l|}
\hline No & Sekolah & Tahun 2016(\%) & Tahun 2017(\%) \\
\hline 1 & MAN I Bungo & $30 \%$ & $37 \%$ \\
\hline 2 & MAN 3 & $51 \%$ & $53 \%$ \\
\hline
\end{tabular}


\begin{tabular}{|l|l|l|l|}
\hline 3 & MAN 2 & $35 \%$ & $39 \%$ \\
\hline \multicolumn{3}{|c|}{ Perilaku seperti diatas menunjukkan adanya kesenjangan antara }
\end{tabular} cita-cita dan tujuan pendidikan nasional di satu pihak dan hasil yang diharapkan di pihak lain. Kesenjangan ini mengandaikan adanya sesuatu atau mungkin beberapa hal yang salah dalam proses pendidikan. Diantaranya terkait dengan pengarh satu komponen terhadap komponen yang lain di dalam pendidikan.kondisi tersebut menuntut tindakan nyata dari semua pihak: pemerintah, orang tua, sekolah dan masyarakat agar agresivitas siswa tidakan menjadi semakin terkendali.

\section{B. Metodologi Penelitian}

Penelitian ini adalah penelitian kuantitatif dengan pendekatan survey yaitu suatu penelitian yang dilakukan melalui pengamatan langsung terhadap suatu gejala atau pengumpulan informasi dari populasi besar maupun kecil, tetapi data yang dipelajari adalah data dari sampel sebagai mewakili data populasi tersebut. Dalam penelitian ini, peneliti berusaha menjelaskan terjadi hubungan saling mempengaruhi antar satu variabel dan variabel yang lain berdasarkan besar kecilnya koefesien korelasi.

Teknik pengambilan sampel Multistage random Sampling, artinya sampel dipilih secara random dan berlapis dengan langkah sebagai berikut(1) Pemilihan 3 MAN secara cluster. Hasilnya terpilih MAN 1, MAN 2 dan MAN 3 sebanyak 580 siswa. (2) berdasarkan jumlah siswa kelas II tersebut, dilakukan penentuan jumlah sampel melalui rumus Tuckman sebesar 263 responden. Adapun teknik pengambilan sampel adalah sbb: jumlah siswa dari tiga sekolah secara keseluruhan adalah 2600 orang, sedangkan siswa kelas II adalah 780 orang penentuan besar sampel. menggunakan rumus :

$$
\begin{aligned}
& \mathrm{N}=(\mathrm{z})^{2}(\mathrm{p})(\mathrm{q}) \\
& \mathrm{e}- \\
& \text { Dimana }: \mathrm{n}=\text { besar sampel } \\
& \mathrm{Z}=\text { nilai standar dengan tingkat signifikasi }(\alpha=0,005) \\
& \mathrm{E}=\text { kesalahan penaksiran maksimum yang dapat diterima } \\
& \mathrm{P}=\text { perkiraan proporsi pada populasi }
\end{aligned}
$$




$$
\mathrm{Q}=1-\mathrm{p} .^{14}
$$

Teknik pengumpulan data melalui observasi, kuesioner dan dokumentasi dengan menggunakan teknik angket

Daftar Nilai (Skor) Skala Rating.

\begin{tabular}{|l|l|l|l|}
\hline No & Alternatif jawaban & \multicolumn{1}{|c|}{ Skor (+) } & Skor (-) \\
\hline 1 & SL (selalu) & 5 & 1 \\
\hline 2 & SR (sering) & 4 & 2 \\
\hline 3 & KK (kadang-kadang) & 3 & 3 \\
\hline 4 & JR (Jarang) & 2 & 4 \\
\hline 5 & TP (tidak pernah) & 1 & 5 \\
\hline
\end{tabular}

serta uji validitas instrument menggunakan SPSS atau dapat menggunakan korelasi product moment dengan rumus yang dikemukakan oleh person sebagai berikut : ${ }^{15}$

$$
\begin{aligned}
& \quad r_{x y}=\frac{N \sum x y-\left(\sum x\right)\left(\sum y\right)}{\sqrt{\left\{N \sum_{x}^{2}-\left(\sum x\right)^{2}\right\}\left\{N \sum y^{2}-\left(\sum y\right)^{2}\right\}}} \\
& \sum \sum \sum \\
& \text { Keterangan : } \\
& \text { koefisien korelasi antara variabel X dan Y } \\
& \mathrm{N}=\text { jumlah responden } \\
& \text { rxy = jumlah perkalian antara skor variabel X dan skor } \\
& \text { variabel Y } \\
& \text { rX = jumlah skor variabel X } \\
& \text { ry = jumlah skor variabel Y } \\
& \text { Validitas Instrumen Angka Korelasi Makna } \\
& 0,800-1.000 \text { Sangat Valid } \\
& 0.400-0.600 \text { Cukup Valid } \\
& 0.000-0.200 \text { Tidak Valid }
\end{aligned}
$$

Uji Reabilitas Instrumen menggunakan SPSS Windows untuk menghitung kereabilitasan suatu instrumen namun, penelitian juga dapat menggunakan hitung manual dengan rumus seperti:

14 Bruce W. Tuckman. Conducting Educational Research, Second Edition (New York: Harcourt Brace Jovanavich,Inc, 2000), h. 232.

${ }^{15}$ Sudjana. Metode Statistik (Bandung: Tarsito, 2001), h. 45-70. 


$$
\begin{aligned}
& r_{11=}\left(\frac{K}{K-1}\right)\left(\frac{V_{t-}-\sum p_{q}}{V_{t}}\right) \\
& \text { Keterangan } \quad r_{11}=\text { Tes realibilitas } \\
& \mathrm{k}=\text { nomor } \\
& V_{t=} \text { jumlah varians } \\
& p=\text { bagian yang menjawab benar per nomor soal } \\
& \text { kriteria realibiltas sebagai berikut : } \\
& \quad \text { kategori reabilitas: } \\
& \text { jika } 0,90 \leq r_{11}<1,00 \text {, sangat tinggi } \\
& \text { jika } 0,70 \leq r_{11}<0,90 \text {, tinggi } \\
& \text { jika } 0,40 \leq r_{11}<0,70 \text {, sedang } \\
& \text { jika } 0,20 \leq r_{11}<0,40 \text {, rendah } \\
& \text { jika } 0,00 \leq r_{11}<0,20 \text {, sangat rendah. }
\end{aligned}
$$

Serta Teknik Analisi Data melalui Uji Normalitas dengan menggunakan rumus uji kolmogorov. Pada perhitungan diperoleh Lhitung $<\mathrm{L}_{\text {tabel }}$ maka dinyatakan bahwa data normal. Dan Uji Hipotesis Untuk menguji $\mathrm{X} 1, \mathrm{X} 2$ dan $\mathrm{Y}$, maka analisis yang digunakan digunakan adalah uji-t dan ANOVA. Uji-t dan ANOVA adalah salah satu uji statistik yang digunakan untuk mengetahui ada atau tidaknya pengaruh yang signifikan antara variable. Adapun Uji hipotesis 1 dan 2 di dianalisis menggunakan uji-t dan uji hipotesis nomor 3 menggunakan ANOVA. Peneliti menganalisis data menggunakan SPSS. Kriteria pengujian yang berlaku adalah jika $t$ table $\leqslant t$ hitung maka $\mathrm{H}_{0}$ diterima dan Ha ditolak, jika $t_{\text {hitung }}<t_{\text {tabel }}$ dengan derajat kebebasan $(d k)=(n-1)$ dan taraf signifikan $5 \%, \alpha=0,05$ ”

\section{Pembahasan}

\section{Temuan Penelitian}

Penelitian ini adalah penelitian kuantitatif dengan pendekatan survey yang diadakan di MAN Kabupaten Bungo pada tahun 2018. Variable penelitian ini meliputi pengetahuan agama, pertimbangan moral dan agresivitas siswa. Sampel dalam penelitian ini berjumlah 263 siswa MAN Kabupaten Bungo terdiri dari MAN 1, MAN 2 dan MAN 
3. Sampel siswa untuk MAN 1 sebanyak 88 siswa, kemudian siswa untuk MAN 2 juga sebanyak 88 siswa sedangkan siswa MAN 3 berjumlah 87. Dalam proses penelitian, angket/kuesioner disebarkan ke 3 Madrasah Aliyah Negeri Bungo. Hasil penelitian dijelaskan sebagai berikut:

Descriptive Statistics

\begin{tabular}{|l|r|r|r|}
\hline & Mean & Std. Deviation & N \\
\hline Agresivitas Siswa & 69.07 & 15.417 & 263 \\
Pengetahuan Agama & 99.79 & 14.152 & 263 \\
Pertimbangan Moral & 82.97 & 14.662 & 263 \\
\hline
\end{tabular}

Berdasarkan tabel di atas, rata-rata agresivitas siswa 69,07, sedangkan standar deviasi 15,417. Kemudian rata-rata untuk pengetahuan agama sebesar 99.79 dan untuk standar deviasinya 14,152. Rata-rata untuk pertimbangan moral adalah 82.97 dan standar deviasi adalah 14,662.

\section{a. Uji Validitas}

Hasil uji coba kuesioner tentang pengetahuan agama, pertimbangan moral dan agresivitas siswa MAN Kabupaten Bungo sebanyak 30 penyataan setiap variabelnya, hasil analisis uji validitas disajikan pada lampiran. Hasil analisis dalam uji validitas yang tidak valid 3 item untuk kuesioner pengetahuan agama. Kemudian untuk kuesioner pertimbangan moral 4 penyataan tidak valid. Sedangkan untuk kuesioner agresivitas pernyataan tidak valid sebanyak 4 pernyataan. Berikut tabel analisis uji validitas.

\begin{tabular}{|l|l|l|}
\hline \multicolumn{1}{|c|}{ Variabel } & Diterima & Ditolak \\
\hline Pengetahuan Agama & 27 & 3 \\
\hline Pertimbangan Moral & 26 & 4 \\
\hline Agresivitas Siswa & 26 & 4 \\
\hline
\end{tabular}

Untuk mengetahui validitas instrument, angka $r$ hitung dibandingkan dengan $t$ table dengan signifikan 0,05. Jika $r$ hitung lebih tinggi dari t table maka item penyataan diterima. 


\section{b. Uji Realibiltas}

Berdasarkan hasil analisis uji coba soal yang telah dilakukan maka diperoleh nilai $\mathrm{r} 11=0,823$ untuk kuesioner pengetahuan agama. Hasil analisis diperoleh dari kuesioner pertimbangan moral nilai $\mathrm{r} 11=0,772$. Setelah dianalisi uji realibilitas kuesioner agresivitas siswa diperoleh nilai $\mathrm{r} 11=0,872$. Nilai reliabilitas seluruh tes dengan menggunakan rumus metode alpha cronbach pada taraf signifikan $5 \%$. instrumen di atas dinyatakan reliabel dengan tingkat reliabilitas yang kuat dan reliabilitas tes tinggi.

\section{c. Uji Normalitas}

Uji normalitas dalam penelitian ini dianalisis dengan menggunakan uji Kolmogorov-Smirnov dengan menggunakan SPSS 16.0. Hasil tes dapat dilihat pada tabel di bawah ini:

One-Sample Kolmogorov-Smirnov Test

\begin{tabular}{|ll|r|r|r|}
\hline & & $\begin{array}{c}\text { pengetahuan } \\
\text { agama }\end{array}$ & $\begin{array}{c}\text { pertimabang } \\
\text { an moral }\end{array}$ & $\begin{array}{c}\text { agresivitas } \\
\text { siswa }\end{array}$ \\
\hline $\mathrm{N}$ & Mean & 263 & 263 & 263 \\
Normal & Std. & & & \\
Parameters & & & \\
& Deviatio & 14.15175 & 14.66220 & 15.41685 \\
& $\mathrm{n}$ & & & \\
Most Extreme & Absolute & .058 & .051 & .079 \\
Differences & Positive & .058 & .045 & .079 \\
& Negative & -.033 & -.051 & -.055 \\
Kolmogorov-Smirnov Z & .942 & .833 & 1.284 \\
Asymp. Sig. (2-tailed) & .338 & .491 & .074 \\
\hline
\end{tabular}

Test distribution is Normal. 
Berdasarkan tabel di atas, dapat dilihat uji normalitas terdistribusi secara normal, hal ini dibuktikan dengan hasil uji probabilitas pada SPSS yaitu lihat pada nilai Asymp. Sig. (2-tailed) nilainya 0,338 dimana $>0,05$ yang artinya data berdistribusi normal.

Histogram

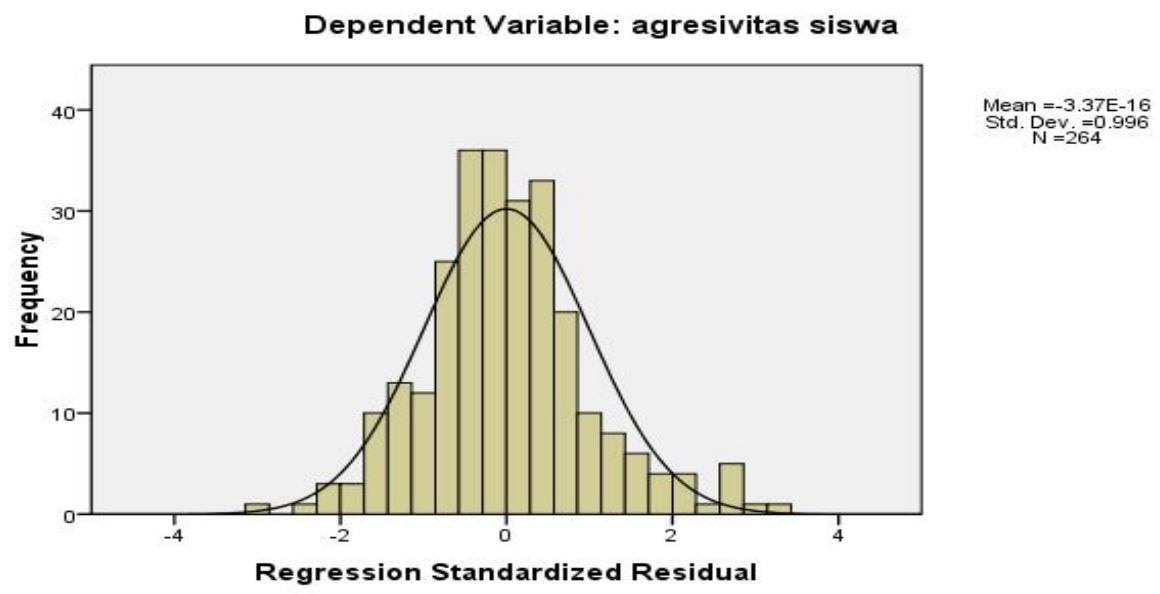

Berdasarkan histogram diatas dapat disimpulkan data menyebar disekitar garis diagonal. Ini menunjukan pola distribusi normal, maka model regresi memenuhi asumsi normalitas. 

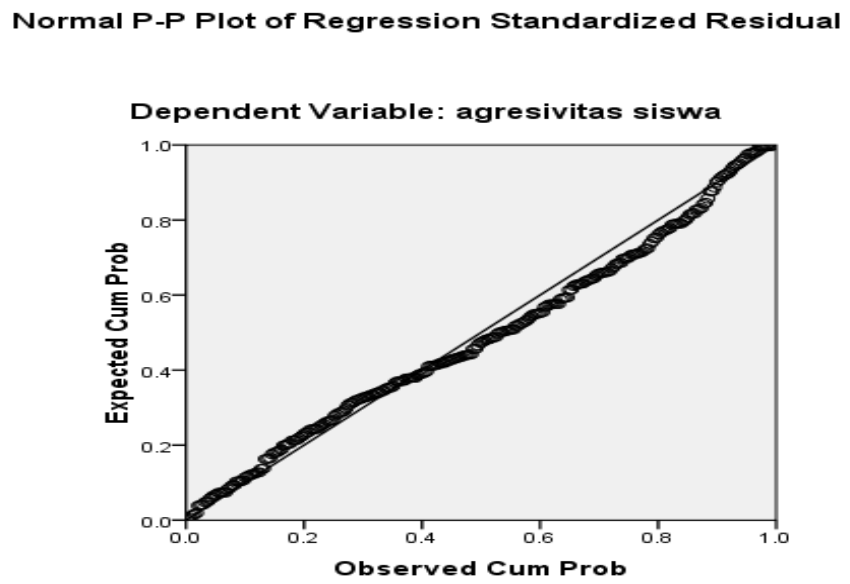

Berdasarkan histogram diatas dapat disimpulkan data merata di garis dan tidak menjauh dari dari garis tengah. Ini menunjukan pola distribusi normal, maka model regresi memenuhi asumsi normalitas.

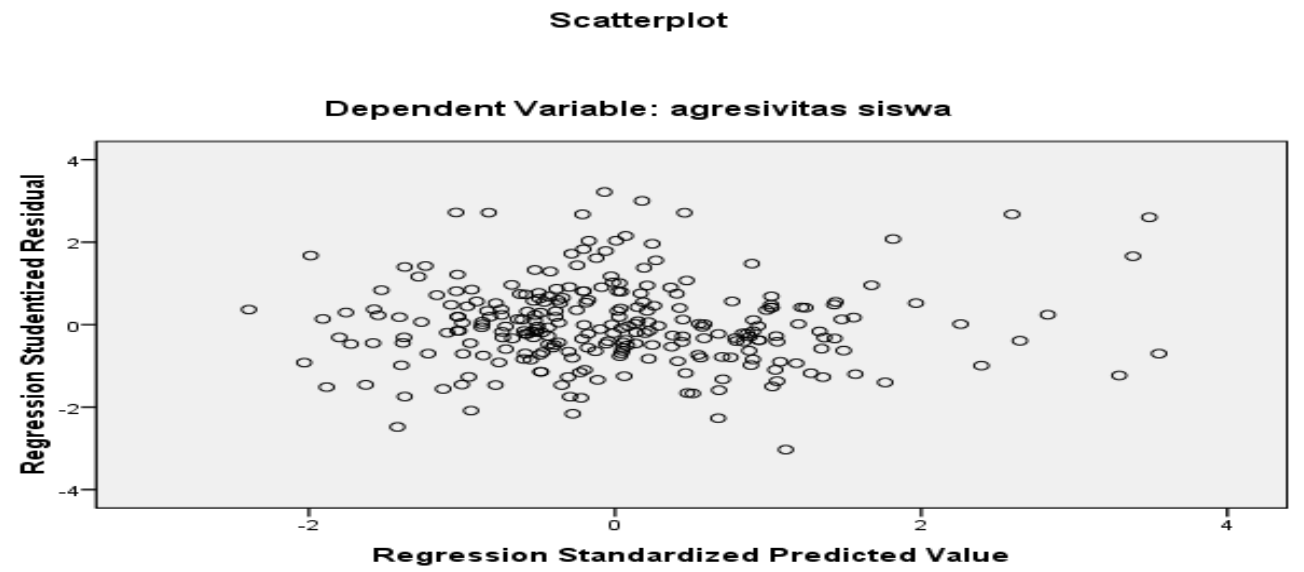

Jika dilihat dari histogram di atas plot menyebar merata di atas dan di bawah sumbu dan tidak membentuk sebuah pola tertentu, maka 
dinyatakan tidak ada gejala heteroskedastisitas. Selanjutnya normalitas dapat dideteksi peneyebaran pada sumbu diagonal dari grafik.

\section{d. Uji Regresi}

Pada uji regresi dianalisis menggunakan SPSS. Hasil uji dapat dilihat di table ini:

\begin{tabular}{|l|l|r|r|r|r|}
\hline Model & R & R Square & $\begin{array}{c}\text { Adjusted R } \\
\text { Square }\end{array}$ & $\begin{array}{r}\text { Std. Error of } \\
\text { the Estimate }\end{array}$ & $\begin{array}{l}\text { Durbin- } \\
\text { Watson }\end{array}$ \\
\hline 1 & $.202^{\mathrm{a}}$ & .041 & .037 & 15.129 & \\
2 & $.309^{\mathrm{b}}$ & .095 & .088 & 14.721 & 1.649 \\
\hline
\end{tabular}

a. Predictors: (Constant), pertimabangan moral

b. Predictors: (Constant), pertimabangan moral, pengetahuan agama

c. Dependent Variable: agresivitas

siswa

Pada table ini memberikan informasi tentang besarnya pengaruh dari seluruh variable independent terhadap variable dependen. Pengaruh tersebut disimbolkan nilai pada kolom $\mathrm{R}$ yaitu 0,202 dan 0,309. terlihat nilai R square sebesar 0,041 dan 0,095.

\section{e. Uji Hipotesis}

Berdasarkan hasil pengolahan data melalui program SPSS uji hipotesis sebagai berikut:

\begin{tabular}{|l|c|c|c|c|c|}
\hline \multirow{4}{*}{ Model } & \multicolumn{2}{|c|}{ Coefficients $^{\mathrm{a}}$} \\
& $\begin{array}{c}\text { Unstandardized } \\
\text { Coefficients }\end{array}$ & $\begin{array}{c}\text { Standardized } \\
\text { Coefficients }\end{array}$ & & \\
\cline { 2 - 4 } & $\mathrm{B}$ & Std. Error & Beta & T & Sig. \\
\hline
\end{tabular}




\begin{tabular}{|c|c|c|c|c|c|c|}
\hline 1 & $\begin{array}{l}\text { (Constant) } \\
\text { Pertimbangan } \\
\text { Moral }\end{array}$ & $\begin{array}{r}51.485 \\
.212\end{array}$ & $\begin{array}{r}5.361 \\
.064\end{array}$ & .202 & $\begin{array}{l}9.604 \\
3.331\end{array}$ & $\begin{array}{l}.000 \\
.001\end{array}$ \\
\hline 2 & (Constant) & 70.020 & 7.001 & & $\begin{array}{r}10.00 \\
1\end{array}$ & .000 \\
\hline & $\begin{array}{l}\text { Pertimbangan } \\
\text { Moral }\end{array}$ & .326 & .068 & .310 & 4.778 & .000 \\
\hline & $\begin{array}{l}\text { Pengetahuan } \\
\text { Agama }\end{array}$ & -.281 & .071 & -.258 & 3.968 & .000 \\
\hline
\end{tabular}

a. Dependent

Variable: agresivitas

siswa

1) Uji Hipotesis I

Ho : Tidak terdapat pengaruh pengetahuan agama terhadap agresivitas siswa MAN Kabupaten Bungo

Ha : terdapat pengaruh pengetahuan agama terhadap

agresivitas siswa MAN Kabupaten Bungo

Untuk melakukan pengujian hipotesis tersebut akan dilakukan teknik statistik uji t. Perhitungan signifikansi pada uji t dihitung berdasarkan perbandingan antara $t$ hitung dengan $t$ tabel. Jika nilai $t$ hitung lebih besar dari $t$ tabel dengan mempertimbangkan tingkat signifikansi tertentu maka dapat disimpulkan bahwa pengetahuan agama memiliki pengaruh terhadap agresivitas siswa MAN Kabupaten Bungo. Namun jika $t$ hitung lebih kecil dari $t$ tabel dengan memperhitungkan tingkat signifikansi tertentu maka berarti variabel pengetahuan agama tidak memiliki pengaruh terhadap agresivitas siswa MAN Kabupaten Bungo.

2) Uji Hipotesis II

Ho : Tidak terdapat pengaruh pertimbangan moral terhadap agresivitas siswa MAN Kabupaten Bungo.

Ha : terdapat pengaruh pertimbangan moral terhadap agresivitas siswa MAN 
Pengujian hipotesis ini akan menggunakan teknik statistik uji t (t-test). Dalam metode penelitian bahwa uji statistik digunakan untuk mengetahui apakah variabel bebas yang dimasukkan dalam model secara parsial memiliki pengaruh signifikan terhadap variabel terikat.

Metode yang digunakan adalah dengan cara membandingkan antara nilai t hitung dengan $t$ tabel pada tingkat signifikansi tertentu. Jika t hitung lebih besar dari t tabel maka variabel pertimbangan moral terhadap agresivitas siswa MAN Kabupaten Bungo. sebaliknya jika $t$ hitung lebih kecil dari $t$ tabel maka variabel pertimbangan moral terhadap agresivitas siswa MAN Kabupaten Bungo tidak memiliki pengaruh terhadap variabel terikat.

3) Uji Anova

Dalam penelitian ini, peneliti menggunakan rumus ANOVA tanpa bobot dalam menganalisis interaksi antara pengetahuan agama dan pertimbangan moral terhadap agresivitas siswa MAN Kabupaten Bungo. Hasil analisis dapat dilihat pada tabel di bawah ini:

\begin{tabular}{|ll|r|r|r|r|r|}
\hline \multicolumn{1}{|c|}{ Model } & \multicolumn{1}{|c|}{$\begin{array}{c}\text { Sum of } \\
\text { Squares }\end{array}$} & Df & Mean Square & F & Sig. \\
\hline 1 & Regression & 2540.337 & 1 & 2540.337 & 11.098 & $.001^{\mathrm{a}}$ \\
& Residual & 59969.295 & 262 & 228.890 & & \\
& Total & 62509.633 & 263 & & & \\
\hline $2 \quad$ Regression & 5952.568 & 2 & 2976.284 & 13.735 & $.000^{\mathrm{b}}$ \\
& Residual & 56557.065 & 261 & 216.694 & & \\
& Total & 62509.633 & 263 & & & \\
\hline
\end{tabular}

a. Predictors: (Constant), pertimabangan moral

b. Predictors: (Constant), pertimabangan moral, pengetahuan agama

c. Dependent Variable: agresivitas siswa 
Berdasarkan table diatas, f hitung 11.098 sedangkan $\mathrm{f}$ table 3.05, dapat disimpulkan $\mathrm{f}$ hitung $>\mathrm{f}$ table. Jika $\mathrm{f}$ hitung lebih besar dari $\mathrm{f}$ table maka Ha diterima.

2. Pembahasan

a. Pengaruh pengetahuan agama terhadap agresivitas siswa MAN Kabupaten Bungo

Hasil penelitian untuk uji hipotesis yang pertama dapat disimpulkan bahwasanya variable pengetahuan agama terdapat pengaruh terhadap variable agresivitas siswa MAN. Hasil penelitian ini sejalan dengan beberapa penelitian terdahulu diantaranya adalah penelitian Hairul Umah yang menemukan bahwa tingkat religiusitas pada remaja dalam tingkat sedang. Ini terjadi dipengaruhi oleh beberapa faktor.

Ditinjau dari hasil uji $t$ dapat mengindikasikan bahwa pengetahuan agama siswa dalam kategori sedang dan belum diaplikasikan secara maksimal. Dengan demikian hipotesis pertama Ho ditolak maka Ha diterima. T hitung 3,331 > t tabel 1,652 maka dapat dikatakan bahwa pengetahuan agama memiliki pengaruh terhadap agresivitas siswa MAN Kabupaten Bungo.

Bloom, mengemukakan bahwa pendidikan tidak hanya membuat peserta didik menjadi orang yang kaya ilmu pengetahuan dan teori, tetapi juga membentuk manusia yang mampu berprilaku baik di dalam masyarakat sekaligus terampil dalam mempraktikkan ilmu yang dimilikinya. Darajat mengatakan agama yaitu proses hubungan manusia yang dirasakan terhadap sesuatu yang diyakininya ${ }^{15}$ Dalam Islam hendaknya pengetahuan agama diaplikasikan dalam kehidupan sehari-hari sehingga tercermin perilaku yang diajarkan oleh agama. Berdasarkan hasil pengamatan fenomena di MAN Kabupaten Bungo. Pengetahuan agama masih dalam kategori sedang. Namun, pengetahuan agama yang dimiliki siswa MAN Kabupaten Bungo belum sepenuhnya diterapkan dalam kehidupan sehari-hari.

15 Darajat, Ilmu Jiwa Agama (Jakarta: Bulan Bintang, 2005), h. 10. 
b. Pengaruh pertimbangan moral terhadap agresivitas siswa MAN Kabupaten Bungo

Hasil pengujian hipotesis kedua menunjukan bahwa pertimbangan moral berpengaruh terhadap agresivitas siswa MAN. Dalam penelitian ini diperoleh $t$ hitung sebesar 3,968 dan t tabel 1,652 dengan responden sebanyak 263 pada taraf signifikansi $5 \%$. T hitung lebih besar dari t tabel $(3,968>1,652)$ atau sig $(0,00<0,05)$. Dengan demikian hipotesis kedua Ho ditolak maka Ha diterima maka dapat dikatakan bahwa pertimbangan moral mempunyai pengaruh terhadap agresivitas siswa MAN Kabupaten Bungo.

Dalam hal ini, Menurut Dewey dalam Ali dan Asrori, moral berarti hal-hal yang berhubungan dengan nilai-nilai susila. ${ }^{16}$ Sedangkan menurut Baron Moral adalah hal yang berhubungan dengan larangan dan tindakan yang berbicara tentang salah atau benar. Berdasarkan teori tersebut moral ada kaitannya dengan akhlak.

Berdasarkan penjelasan di atas maka dapat dikatakan bahwa semakin tinggi pertimbangan moral, maka akan semakin minim perilaku agresivitas siswa MAN Kabupaten Bungo. Dengan demikian, pertimbangan moral memiliki pengaruh terhadap agresivitas siswa MAN Kabupaten Bungo. Mempertimbangkan moral dapat menciptakan hubungan antar indidvidu yang baik serta meminimalisir perilaku agresivitas.

\section{c. Pengetahuan agama dan pertimbangan moral berpengaruh terhadap agresivitas siswa MAN Kabupaten Bungo}

Berdasarkan hasil analisis hipotesis ketiga Ho ditolak maka Ha diterima jika f hitung $>\mathrm{f}$ table maka Ho di tolak dan Ha diterima. $\mathrm{F}$ hitung 11,098 dan $\mathrm{f}$ table 3,05 maka pengetahuan agama dan pertimbangan moral memiliki pengaruh terhadap agresivitas siswa MAN kabupaten Bungo. Dengan demikian, dapat disimpulkan bahwa hipotesis terdapatnya pengaruh pengetahuan agama dan pertimbangan moral terhadap agresivitas siswa MAN Kabupatn Bungo diterima.

16 Ali Mohd dan Asrori Mohd. Psikologi, h. 136. 
Hasil beberapa penelitian terdahulu diantaranya adalah penelitian siti nurmadiyah dengan judul "hubungan antara religusitas dengan agresivitas pada remaja di SMK Muhammadiyah 1 Surakarta”. Religiusitas memiliki rerata empirik (RE) sebesar 110,06 dan rerata hipotetik ( $\mathrm{RH})$ sebesar 90,00 sehingga memiliki kategorisasi yang tergolong tinggi, sedangkan untuk agresivitas memiliki rerata empirik (RE) sebesar 49,93 dan rerata hipotetik (RH) sebesar 65,0, sehingga memiliki kategorisasi yang tergolong rendah. Sumbangan efektif yang diperoleh atau peranan religiusitas terhadap agresivitas adalah sebesar 19,8\% ditunjukkan oleh koefisian $\mathrm{r}^{2}$ (korelasi determinan) sebesar 0,198 sisanya 80,2\% dipengaruhi oleh faktor lain.

Pengertian perilaku agresif yang dinyatakan oleh Buss dan Perry (dalam Oktavia, 2014) adalah kecenderungan perilaku yang bermaksud menyakiti orang lain, baik secara fisik maupun non fisik untuk mengekspresikan perasaan negatifnya sehingga keinginannya tercapai. Berbagai faktor dapat menjadi penyebab perilaku agresivitas, baik faktor eksternal maupun internal. Kemudian, Davdoff (dalam izzaty, menyatakan bahwa faktor eksternal penyebab agresivitas adalah lingkungan. ${ }^{17}$ Faktor lingkungan yang dimaksud adalah: kemiskinan, anominitas, suhu udara yang panas dan meniru (modelling). Sedangkan faktor internal tersebut adalah faktor biologis. Faktor-faktor biologis yang mempengaruhi perilaku agresi yaitu transmisi genetik, sistem otak, dan kimia darah.

\section{Penutup}

Berdasarkan hasil penelitian dan pembahasan, maka diperoleh simpulan sebagai berikut:

1. Terdapat pengaruh pengetahuan agama terhadap agresivitas siswa MAN Kabupaten Bungo dengan koofesien korelasi 3,968.

2. Terdapat pengaruh pertimbangan moral terhadap agresivitas siswa MAN Kabupaten Bungo dengan koofesien korelasi 3,331.

17 Izzaty E, Rita, Mengenali Perkembangan Anak TK (Jakarta: Departemen Pendidikan Nasional.,2005), h. 107. 
Pengaruh Pengetahuan Agama ...

3. Terdapat pengaruh pengetahuan agama dan pertimbangan moral terhadap agresivitas siswa MAN Kabupaten Bungo dengan koofesien korelasi 11,098.

\section{Daftar Pustaka}

Ali Mohd dan Asrori Mohd. Psikologi Remaja: Perkembangan Peserta Didik. Jakarta : Bumi Aksara, 2004.

Anderson Lorin W And David R. Krathwoh. A. Taxonomi For Learning, Teaching and Assessing : A Revision of Blooms Taxonomy of Educational Objecteves. New York: Addison Wsley Longman,Inc, 2001.

Azwar Saifuddin. Reliabilitas dan Validitas. Yogyakarta: Pustakawa Pelajar, 2000.

Barger Robert N. “A Summy of Lawrence Kohlberg's Stages of Moral Developmnet” Makalah. Notre Dame: University of Notre Dame, 2000.

Budiningsih. Pembelajaran Moral. Jakarta: Rineka Cipta, 2004.

Bruce W. Tuckman. Conducting Educational Research, Second Edition. New York: Harcourt Brace Jovanavich, Inc, 2000.

Elizabeth Hurlock B. Perkembangan Anak, Jilid 4, Edisi Keenam. Jakarta: Erlangga, 2000.

Gilliland et.al. Theories and Stategies in Counseling and Psychoteraphy. New Jersey: Prentice Hall Inc, 1999. 
Harapan Ponpon. “Agresi Pada Remaja "Makalah disampaikan pada seminar Tindakan Kekerasan dan Agresi di Kalangan Anak dan Remaja. Bandung 07 Sepetember 1991.

Mark Ruth. Aggression. 2002 (http://specialed.about.com/cs/behavior encourders/a/aggression.html).

Mahfuzh Jamaluddin. Psikologi Anak dan Remaja Muslim. Jakarta: Pustaka Al-Kautsar, 2001.

Sears David o.et.al. Psikologi Sosial. Jakarta: Erlangga, 1991.

Sudjana. Metode Statistik. Bandung: Tarsito, 2001.

Yusuf Syamsu. Psikologi Perkembangan Anak dan Remaja. Bandung: Remaja Rosdakarya, 2004. 